\title{
In Vitro Assessment of Dentin Erosion after Immersion in Acidic Beverages: Surface Profile Analysis and Energy-Dispersive X-Ray Fluorescence Spectrometry Study
}

\author{
Taciana Marco Ferraz CANEPPELE ${ }^{1}$ \\ Raffaela Di Iorio JERONYMO ${ }^{1}$ \\ Rebeca Di NICOLÓ ${ }^{1}$ \\ Maria Amélia Máximo de ARAÚJO1 \\ Luís Eduardo Silva SOARES ${ }^{2}$ \\ ${ }^{1}$ Department of Restorative Dentistry, São José dos Campos Dental School, \\ UNESP - Univ Estadual Paulista, São José dos Campos, SP, Brazil \\ ${ }^{2}$ Laboratory of Biomedical Vibrational Spectroscopy, Institute of Research and Development (IP\&D), \\ UNIVAP - University of Vale do Paraíba, São José dos Campos, SP, Brazil
}

\begin{abstract}
The aim of this study was to investigate the effects of some acidic drinks on dentin erosion, using methods of surface profile (SP) analysis and energy-dispersive X-ray fluorescence spectrometry (EDXRF). One hundred standardized dentin slabs obtained from bovine incisor roots were used. Dentin slabs measuring $5 \times 5 \mathrm{~mm}$ were ground flat, polished and half of each specimen surface was protected

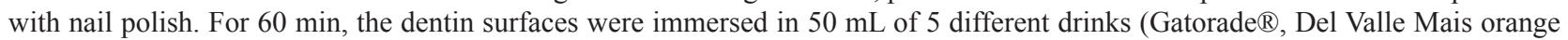
juice ${ }^{\circledR}$, Coca-Cola ${ }^{\circledR}$, Red Bull ${ }^{\circledR}$ and white wine), 20 blocks in each drink. The pH of each beverage was measured. After the erosive challenge, the nail polish was removed and SP was analyzed. The mineral concentration of dentin surfaces was determined by means of EDXRF. Data were analyzed statistically by ANOVA and Tukey's test $(\alpha=0.05)$. SP analysis showed that Red-Bull had the highest erosive potential $(\mathrm{p}<0.05)$. EDXRF results exhibited a decrease in phosphate in the groups immersed in Red-Bull, orange juice and white wine $(\mathrm{p}<0.05)$, and no significant difference in calcium content between the reference surface and eroded surface. In conclusion, this study demonstrated that all studied beverages promoted erosion on root dentin and Red Bull had the highest erosive potential. There was no correlation between $\mathrm{pH}$ of beverages and their erosive potential and only the $\mathrm{P}$ content changed after erosive challenge.
\end{abstract}

Key Words: dental erosion, X-ray fluorescence spectrometry, $\mathrm{pH}$, beverages.

\section{INTRODUCTION}

Tooth erosion is the loss of dental structure by acid dissolution that does not involve bacteria (1). Erosion is classified as being of extrinsic origin when dependent on diet, or intrinsic when it is due to gastroesophageal problems. Erosion is typically progressive and results in the wear of exposed tooth surface, initially the enamel followed by dentin. In Europe and the Middle East, dental erosion is considered as a significant oral disease (2).

Dentinal hypersensitivity (DH) can be described as a painful condition that appears through dentin exposure in response to chemical, thermal, tactile, or osmotic stimuli, which cannot be explained as being the result of any other form of dental defect or pathology. However, the factors that expose dentin and the dentinal tubules are not clearly defined. Greater attention has been paid to treatment, and little emphasis has been given to knowledge of the etiologic factors, which are essential in the prevention of occurrence and recurrence of this condition as well as in its treatment. DH seems to have a multifactorial etiology, but one of the main causes is assumed to be patient's diet. Evidence from in vitro studies indicates that acid substances can cause loss of the tooth structure (erosion) or remove the smear layer and expose the dentinal tubules. In 1990, Clark et al. (3) observed a negative association between the frequency of acid food and beverage intake and the persistence of DH. 
The occurrence of tooth erosion has been consistently reported in the literature as case reports and control studies, and wide access to and frequent consumption of acid beverages have led to increasing prevalence of tooth erosion (4).

The decalcified enamel and dentin surfaces become soft and more susceptible to wear by brushing and masticatory forces. In people with low concentrations of calcium and phosphate, the critical $\mathrm{pH}$ for hydroxyapatite decalcification may be 6.5 , while in those with high concentrations of calcium and phosphate, the critical pH may be 5.5. Wine, for example, contains tartaric and malic acids combined with small amounts of lactic, succinic and citric acid. This results in a $\mathrm{pH}$ around 2.9 to 4.2 , far below the critical value for hydroxyapatite decalcification.

Non-alcoholic beverages containing intrinsic acids and sugars have greater acidogenic and cariogenic potential. A positive relationship between caries, consumption of non-alcoholic beverages and erosion has been widely demonstrated (5-7). Therefore, clinical manifestations and diagnosis of diseases caused by nonalcoholic beverages may be attributed to a combination of erosion and caries, and clinicians should pay more attention to the fact (8).

Studies in this field have used traditional analytical tools such as profilometry $(9,10)$ and microhardness tests (9). However, X-ray fluorescence microanalysis has been little used to study erosive effects on root dentin (11). The X-ray fluorescence spectrometry measuring energy-dispersive ions is a nondestructive analytical technique applied to analyze tooth mineral content. The fluorescent radiation emitted by elements due to X-ray radiation is proportional to their content in a tissue (12).

A variety of commercially available juices, soft drinks, isotonic and energy drinks and their frequent consumption, as well as research indicating that the acids may cause damage to the tooth structure, encouraged the authors to conduct a study with the purpose of analyzing the effect of some beverages on the dentinal structure, using surface profile analysis and energy-dispersive $\mathrm{X}$-ray fluorescence spectrometry (EDXRF).

\section{MATERIAL AND METHODS}

\section{Specimen Preparation}

Fifty sound extracted bovine incisors, stored in $0.1 \%$ thymol at $5^{\circ} \mathrm{C}$ for no longer than 2 weeks after extraction, were used in this study. Manual debridement was done with a periodontal curette to remove surfaceadhered organic debris and polishing with a pumice stone paste and water using a Robinson brush (Viking-KG Sorensen, Barueri, SP, Brazil) and a low-speed handpiece (KaVo do Brasil SA, Joinville, SC, Brazil).

The teeth were cut horizontally at the cementoenamel junction and $10 \mathrm{~mm}$ in the apical direction, using carborundum discs (Dentaurum, Pforzheim, Germany) mounted in a low-speed handpiece. Next, the roots were sectioned longitudinally in the buccolingual direction. The fragments were embedded in a self-curing resin block (Jet; Field Clean, São Paulo, SP, Brazil) with the external part of the root facing the surface. The blocks were worn with 320-grit silicon carbide paper in a polishing machine (Polipan 2; Pantec, São Bernardo do Campo, SP, Brazil) under water cooling, in order to obtain a flat dentin surface. After this, the exposed dentin surface was polished with 600-, 1200- and 4000-grit silicon carbide papers. The prepared samples were kept at $100 \%$ relative humidity at $37^{\circ} \mathrm{C}$ in a culture kiln $(502-1$; Fanem, São Paulo, SP, Brazil) and stored in distilled water before erosion began. The dentin blocks were selected by the initial mean surface microhardness, performed in the diagonal half of the samples. One of the halves of the sample was protected with adhesive tape (3M, Sumaré, SP, Brazil), while the other half, after being submitted to Vickers microhardness reading, was sealed with two layers of red nail polish (Revlon Inc., New York, NY, USA). After the nail polish dried, the adhesive tape was removed. Microhardness values of each specimen was used for stratified allocation among 5 subgroups $(\mathrm{n}=10)$, according the beverage used for erosive challenge.

\section{Erosive Challenge}

The $\mathrm{pH}$ of each beverage was measured with a digital pH meter (DM-20; Digimed, São Paulo, SP, Brazil) (Table 1) immediately after opening the bottle/ package. The beverages evaluated in the study were those considered to be most popular in the country (2) and are present in Table 1. All beverages used presented an acid $\mathrm{pH}$, and Coca-Cola had the lowest $\mathrm{pH}$ value. All specimens of the same group remained immersed together in $50 \mathrm{~mL}$ of the tested beverages for $60 \mathrm{~min}$. Right after being removed from the beverages, the specimens were washed under running water for $10 \mathrm{~s}$ and returned to a receptacle containing distilled water. 
Only one erosive challenge was performed. After the immersion period, the nail polish was removed carefully in order to record the surface profile analysis and perform chemical analysis by EDXRF.

\section{Microhardness Analysis}

Dentin microhardness was measured using a microhardness tester (Microhardness Tester FM-700; Future-Tech Corp., Tokyo, Japan) with a Vicker's indenter in order to make a stratified distribution of the samples in the groups to be tested. Five indentations were made in each specimen and the mean value was obtained.

\section{Surface Profile Analysis}

The dentin specimens were analyzed immersed in distilled water to avoid shrinkage (13). The loss of dentin was evaluated by a trained examiner using profilometry (SJ400; Mitutoyo, Tokyo, Japan) in comparison with the reference area. The palpation tip was moved from the reference area to the exposed area $(1.5 \mathrm{~mm})$. The differences in height between the reference and the exposed area were quantified in micrometers $(\mu \mathrm{m})$. Five measurements were made in the center of each specimen, and the mean was obtained.

\section{EDXRF measurements}

After the acid challenge by the beverages, semiquantitative elemental analyses of calcium (Ca) and phosphorus $(\mathrm{P})$ were carried out with an energydispersive micro-X-ray fluorescence spectrometer (model EDX 1300; Shimadzu, Kyoto, Japan), equipped with a rhodium X-ray tube and a $\mathrm{Si}(\mathrm{Li})$ detector cooled by liquid nitrogen (N2). The spectrometer was coupled to a computer system for data acquisition and processing.

Table 1. Beverages used and their respective $\mathrm{pHs}$ and manufacturers.

\begin{tabular}{lcc}
\hline Beverage & $\mathrm{pH}$ & Manufacturer \\
\hline Coca-cola $^{\circledR}$ & 2.16 & Coca-Cola, Porto Real, RJ, Brazil \\
Gatorade $^{\circledR}$ & 2.79 & Ambev, Jaguariúna, SP, Brazil \\
Red Bull $^{\circledR}$ & 3.18 & Red Bull, Fuschl am See, Austria \\
White wine & 3.00 & Finca La Célia, Mendonza, Argentina \\
Del Valle Mais & \\
\hline
\end{tabular}

The voltage in the tube was set at $50 \mathrm{kV}$, with automatic adjustment of the current and incident beam diameter of $50 \mu \mathrm{m}$. Three spectra from each area (reference and eroded) were collected. Three points within the same line were selected so that the first point was located in the center of the irradiated area and two other points were selected $1 \mathrm{~mm}$ from the center. The measurements were performed with a count rate of $100 \mathrm{~s}$ per point (live time) and a dead time of $25 \%$. The energy range of scans was $0.0-40.0 \mathrm{eV}$. The equipment was calibrated and adjusted using certified commercial stoichiometric hydroxyapatite [Aldrich, synthetic Ca10(PO4)6(OH)2, grade $99.999 \%$, lot $10818 \mathrm{HA}$ ] as a reference. The measurements were collected using classic parameters for $\mathrm{Ca}$ and $\mathrm{P} \mathrm{X}$-ray emission. The elements oxygen $(\mathrm{O})$ and hydrogen $(\mathrm{H})$ were used as a chemical balance. Energy calibration was performed using equipmentspecific internal standards.

\section{Statistical Analysis}

Surface profile and EDXRF data were analyzed by ANOVA and the Tukey's test at a significance level of $5 \%$. The relationship between depth of the erosive lesions and $\mathrm{pH}$ of the beverages was assessed using Spearman's correlation test $(\alpha=0.05)$.

\section{RESULTS}

Table 2 presents the mean loss of dentin after the erosive challenge. The group subjected to the erosive challenge with Red-Bull showed the highest loss of dentin, differing significantly from the group exposed to Gatorade $(\mathrm{p}<0.05)$.

The depth of lesions in dentin were not associated with the $\mathrm{pH}$ of the beverages $(\mathrm{r}=0.28 ; \mathrm{p}=0.638)$.

Table 3 shows the Ca values on the reference surfaces and those that suffered erosive challenge. All groups showed similar $\mathrm{Ca}$ values $(p>0.05)$ on the reference surfaces. After the erosive challenge, the $\mathrm{Ca}$ content of all groups did not differ from its respective reference value, but statistically significant differences were observed among the groups. The group challenged by Red Bull presented the highest mineral loss $(\mathrm{p}<0.05)$.

For the $\mathrm{P}$ values, all groups 
presented similar values $(\mathrm{p}>0.05)$ on the reference surfaces. After the erosive challenge, the P content of the groups challenged by orange juice, Red Bull and wine was significantly reduced $(\mathrm{p}<0.05)$. Differences were also observed among the groups (Table 4).

\section{DISCUSSION}

Traditional assessment techniques, such as microhardness $(9,14)$ and profilometry $(15,16)$, have been applied to evaluate the degradation of dental materials and the loss of dental hard tissue by erosive challenges. EDXRF has been used in several studies to evaluate the content of certain substances on the tooth surface. Wiegand et al. (17) used this method to determine the amount of titanium (Ti) and fluoride (F) in the dentin surface of bovine specimens in a study that assessed the ability of some fluoridated compounds to reduce tooth erosion.

In this study, elemental mappings by EDXRF from

Table 2. Results of surface profile analysis.

\begin{tabular}{lc}
\hline Beverage & Mean loss of dentin in $\mu \mathrm{m}$ \\
\hline Coca-cola $^{\circledR}$ & $1.428(0.228) \mathrm{a}, \mathrm{b}$ \\
Del Valle Mais ${ }^{\circledR}$ orange juice & $1.425(0.358) \mathrm{a}, \mathrm{b}$ \\
Red-Bull $^{\circledR}$ & $2.191(0.873) \mathrm{a}$ \\
Gatorade $^{\circledR}$ & $1.259(0.575) \mathrm{b}$ \\
White wine $^{\circledR}$ & $1.526(0.441) \mathrm{a}, \mathrm{b}$ \\
\hline
\end{tabular}

Means followed by the same letters have no statistically significant difference by the Tukey's test $(\alpha=0.05)$. SD $=$ standard deviation is given in parenthesis.

Table 3. Ca values in dentin surface expressed as mean and SD (\%).

\begin{tabular}{lcc}
\hline Beverage & Reference & Erosive challenge \\
\hline Coca-Cola $^{\circledR}$ & $22.8(1.3)^{\mathrm{Aa}^{*}}$ & $22.3(1.4)^{\mathrm{Ab}}$ \\
$\begin{array}{l}\text { Del Valle Mais } \\
\text { orange juice }\end{array}$ & $24.1(1.4)^{\mathrm{Aa}}$ & $21.2(2.6)^{\mathrm{Aa}}$ \\
Red Bull $^{\circledR}$ & $23.2(2.3)^{\mathrm{Aa}}$ & $18.9(2.3)^{\mathrm{Ac}}$ \\
Gatorade $^{\circledR}$ & $24.4(1.3)^{\mathrm{Aa}}$ & $22.4(1.7)^{\mathrm{Ad}}$ \\
White wine $^{\mathrm{Ad}}$ & $24.1(1.7)^{\mathrm{Aa}}$ & $20.7(1.5)^{\mathrm{Aa}}$ \\
\hline
\end{tabular}

Means followed by the same letters do not represent statistically significant difference by the Tukey's test $(\alpha=0.05)$. Uppercase letters compare values before and after the treatment (columns) and lowercase letters compare the difference among the groups (rows). bovine root dentin subjected to erosion, provided data about the mean concentration of the main components of those structures within selected areas.

Erosion after exposure to beverages was not related to the $\mathrm{pH}$ of the beverage, suggesting that the $\mathrm{pH}$ cannot be used to predict the erosive potential. Ehlen et al. (2) also found no relationship between the $\mathrm{pH}$ of the beverages and the degree of erosion. Previous studies observed that erosive potential of a citric beverage is not only related to $\mathrm{pH}$ and concentration of citric acid, but also to the low degree of saturation in relation to both hydroxyapatite and fluorapatite (18), and the presence of cirate, a substance capable of chelating the calcium of saliva and teeth (19). These factors are important and can affect the erosive potential of a solution.

Red Bull was the drink that showed the highest erosive potential, as it produced the greatest loss of dentin tissue and caused the greatest loss of mineral $\mathrm{Ca}$ and $\mathrm{P}$ content. In the study by Ehlen et al. (2), Red Bull also presented a high erosive potential, however, Gatorade caused deeper lesions, both in enamel and on the root surface.

Although Coca-Cola did not show a high erosive potential in the present in vitro study, some clinical studies have shown a strong association between the consumption of cola-type drinks and the prevalence and severity of erosion $(20,21)$.

De Souza Paula et al. (22) observed significant mineral loss of bovine enamel subjected to immersion in Coca-Cola for $72 \mathrm{~h}$. In the present study, little loss of $\mathrm{Ca}$ was observed and in some groups a greater loss of $\mathrm{P}$ was observed after the erosive challenge. These results differ from those found by De Souza Paula et al. (22) probably because the immersion time in the beverages

Table 4. Pvalues in dentin surface expressed as mean and SD (\%).

\begin{tabular}{lcc}
\hline Beverage & Reference & Erosive challenge \\
\hline Coca-Cola $^{\circledR}$ & $12.1(0.6)^{\mathrm{Aa}}$ & $11.6(0.6)^{\mathrm{Ab}}$ \\
$\begin{array}{l}\text { Del Valle Mais } \\
\text { orange juice }\end{array}$ & $12.4(0.6)^{\mathrm{Aa}}$ & $10.4(1.5)^{\mathrm{Ba}}$ \\
Red Bull $^{\circledR}$ & $12.3(1.3)^{\mathrm{Aa}}$ & $8.6(1.5)^{\mathrm{Bc}}$ \\
Gatorade $^{\circledR}$ & $12.6(0.7)^{\mathrm{Aa}}$ & $11.6(1.3)^{\mathrm{Ad}}$ \\
White wine $^{\mathrm{Ad}}$ & $12.6(1.3)^{\mathrm{Aa}}$ & $10.4(1.2)^{\mathrm{Ba}}$ \\
\hline
\end{tabular}

Means followed by the same letters represent no statistically significant difference by the Tukey's test $(\alpha=0.05)$. Uppercase letters compare values before and after the treatment (columns) and lowercase letters compare the difference among the groups (rows). 
was very different in the studies.

The nature of in vitro research and the artificial time of exposure to the beverages are limitations of the study. The laboratory study exposes the tooth to the beverage for a defined period, without considering the consumption rate of the drink, the movement inside the mouth during swallowing, neutralization by saliva, and the remineralization potential of saliva. These limitations could exacerbate the erosion potential observed in all the beverages. Furthermore, it is not possible to match the experimental conditions to the levels of beverage consumption in human beings. Lastly, only 5 beverages were studied and it is possible that other specific beverages may have different erosive effects.

The erosion potential resulting from the consumption of acid beverages is an important consideration to nutritionists, dentists and physicians in counseling patients. The prolonged contact time between the beverage and the enamel surface at the cementoenamel junction increases the possibility of occurring erosion of root dentin $(23,24)$. Salivary flow is stimulated in response to acidity, and under normal circumstances, this is done to remove the acid and reduce erosion. However, individuals with limited salivary flow could have an increase in acid-tooth contact and be at greater risk of erosion. Sanchez and Fernandez de Preliasco (25) reported that children with erosion showed lower rates of salivary flow and buffer capacity than children without erosion.

Tooth erosion associated with the consumption of acid beverages is an area of potential interest to oral health. Patients with high consumption of acid beverages, and decreased salivary flow or mouth breathing may be at increased risk of tooth erosion.

In conclusion, this study demonstrated that all studied beverages promoted erosion on root dentin and Red Bull had the highest erosive potential. There was no correlation between the $\mathrm{pH}$ of beverages and their erosive potential and only the $\mathrm{P}$ content changed after erosive challenge.

\section{RESUMO}

O objetivo deste estudo foi investigar os efeitos de algumas bebidas ácidas sobre a erosão da dentina, utilizando métodos de análise de perfil de superfície (SP) e espectrometria de energia dispersiva de fluorescência de raios X (EDXRF). Cem blocos de dentina padronizados obtidos de raízes de incisivos bovinos foram utilizados. Os blocos de dentina medindo $5 \times 5 \mathrm{~mm}$ foram planificados, polidos e metade de cada superfície das amostras foram impermeabilizados com esmalte para unhas. Por $60 \mathrm{~min}$, as superfícies de dentina foram imersas em $50 \mathrm{~mL}$ de 5 bebidas diferentes (Gatorade, suco de laranja, Coca-Cola, Red Bull e vinho branco), 20 blocos em cada bebida. $\mathrm{O}$ pH de cada bebida foi medido. Após o desafio erosivo, o esmalte de unha foi removido e SP foram analisados. A concentração de minerais das superfícies de dentina foi determinada por meio de EDXRF. Os dados foram analisados estatisticamente por ANOVA e teste de Tukey. $(p<0,05)$. A análise SP mostrou que o Red-Bull apresentou o maior potencial erosivo. Os resultados do EDXRF apresentaram uma diminuição do fosfato dos grupos imersos no Red-Bull, suco de laranja e vinho branco, e não houve diferença significativa no teor de cálcio entre a superfície de referência e a superfície que sofreu erosão. O Red Bull apresentou o maior potencial erosivo sobre a dentina radicular. Não houve correlação entre o pH das bebidas e o seu potencial erosivo.

\section{REFERENCES}

1. Cochrane NJ, Cai F, Yuan Y, Reynolds EC. Erosive potential of beverages sold in Australian schools. Aust Dent J 2009;54:238244; quiz 277.

2. Ehlen LA, Marshall TA, Qian F, Wefel JS, Warren JJ. Acidic beverages increase the risk of in vitro tooth erosion. Nutr Res 2008;28:299-303.

3. Clark DC, Woo G, Silver JG, Sweet D, Grisdale JC. The influence of frequent ingestion of acids in the diet on treatment for dentin sensitivity. J Can Dent Assoc 1990;56:1101-1103.

4. Ablal MA, Kaur JS, Cooper L, Jarad FD, Milosevic A, Higham $\mathrm{SM}$, et al. The erosive potential of some alcopops using bovine enamel: an in vitro study. J Dent 2009;37:835-839.

5. Harding MA, Whelton H, O'Mullane DM, Cronin M. Dental erosion in 5-year-old Irish school children and associated factors: a pilot study. Community Dent Health 2003;20:165-170.

6. Al-Majed I, Maguire A, Murray JJ. Risk factors for dental erosion in 5-6 year old and 12-14 year old boys in Saudi Arabia. Community Dent Oral Epidemiol 2002;30:38-46.

7. Luo Y, Zeng XJ, Du MQ, Bedi R. The prevalence of dental erosion in preschool children in China. J Dent 2005;33:115-121.

8. Cheng R, Yang H, Shao MY, Hu T, Zhou XD. Dental erosion and severe tooth decay related to soft drinks: a case report and literature review. J Zhejiang Univ Sci B 2009;10:395-399.

9. Rios D, Honorio HM, Francisconi LF, Magalhaes AC, de Andrade Moreira Machado MA, Buzalaf MA. In situ effect of an erosive challenge on different restorative materials and on enamel adjacent to these materials. J Dent 2008;36:152-157.

10. Turssi CP, Hara AT, Domiciano SJ, Serra MC. Study on the potential inhibition of root dentine wear adjacent to fluoridecontaining restorations. J Mater Sci Mater Med 2008;19:47-51.

11. Soares LE, Lima LR, Vieira L.de S, Santo AM, Martin AA. Erosion effects on chemical composition and morphology of dental materials and root dentin. Microsc Res Tech 2011;75:703710 .

12. de Carvalho FG, Puppin-Rontani RM, Soares LE, Santo AM, Martin AA, Nociti-Junior FH. Mineral distribution and CLSM analysis of secondary caries inhibition by fluoride/MDPBcontaining adhesive system after cariogenic challenges. J Dent 2009;37:307-314.

13. Attin T, Becker K, Roos M, Attin R, Paque F. Impact of storage conditions on profilometry of eroded dental hard tissue. Clin Oral Investig 2009;13:473-478.

14. Rodrigues E, Delbem AC, Pedrini D, de Oliveira MS. pH-cycling model to verify the efficacy of fluoride-releasing materials in 
enamel demineralization. Oper Dent 2008;33:658-665.

15. Scaramucci T, Hara AT, Zero DT, Ferreira SS, Aoki IV, Sobral MA. Development of an orange juice surrogate for the study of dental erosion. Braz Dent J 2011;22:473-478.

16. Barbosa CS, Kato MT, Buzalaf MA. Effect of supplementation of soft drinks with green tea extract on their erosive potential against dentine. Aust Dent J 2011;56:317-321.

17. Wiegand A, Magalhaes AC, Sener B, Waldheim E, Attin T. TiF(4) and $\mathrm{NaF}$ at $\mathrm{pH} 1.2$ but not at $\mathrm{pH} 3.5$ are able to reduce dentin erosion. Arch Oral Biol 2009;54:790-795.

18. Lussi A, Jaeggi T. Chemical factors. Monogr Oral Sci 2006;20:7787.

19. Meurman JH, Rytomaa I, Kari K, Laakso T, Murtomaa H. Salivary $\mathrm{pH}$ and glucose after consuming various beverages, including sugar-containing drinks. Caries Res 1987;21:353-359.

20. Jensdottir T, Arnadottir IB, Thorsdottir I, Bardow A, Gudmundsson $\mathrm{K}$, Theodors A, et al.. Relationship between dental erosion, soft drink consumption, and gastroesophageal reflux among Icelanders. Clin Oral Investig 2004;8:91-96.
21. Johansson AK, Johansson A, Birkhed D, Omar R, Baghdadi $\mathrm{S}$, Khan N, et al. Dental erosion associated with soft-drink consumption in young Saudi men. Acta Odontol Scand 1997;55:390-397.

22. Paula S de S, Soares LE, do Espírito Santo AM, Martin AA, Cavalli V, Liporoni PC. FT-Raman and energy dispersive X-ray fluorescence spectrometric analyses of enamel submitted to $38 \%$ hydrogen peroxide bleaching, an acidic beverage, and simulated brushing. Photomed Laser Surg 2010;28:391-396.

23. Johansson AK, Lingstrom P, Birkhed D. Comparison of factors potentially related to the occurrence of dental erosion in high- and low-erosion groups. Eur J Oral Sci 2002;110:204-211.

24. Coombes JS. Sports drinks and dental erosion. Am J Dent 2005;18:101-104.

25. Sanchez GA, Fernandez De Preliasco MV. Salivary pH changes during soft drinks consumption in children. Int J Paediatr Dent 2003;13:251-257.

Received June 25, 2011

Accepted May 22, 2012 